Georgetown University Law Center

Scholarship @ GEORGETOWN LAW

2019

Parol Evidence Rules and the Mechanics of Choice

Gregory Klass

Georgetown University Law Center, gmk9@law.georgetown.edu

This paper can be downloaded free of charge from:

https://scholarship.law.georgetown.edu/facpub/2048

https://ssrn.com/abstract=3150616

Gregory Klass, Parol Evidence Rules and the Mechanics of Choice, 20 Theoretical Inq. L. 457 (2019).

This open-access article is brought to you by the Georgetown Law Library. Posted with permission of the author. Follow this and additional works at: https://scholarship.law.georgetown.edu/facpub

Part of the Contracts Commons, and the Evidence Commons 


\title{
Parol Evidence Rules and the Mechanics of Choice
}

\begin{abstract}
Gregory Klass*
Scholars have to date paid relatively little attention to the rules for deciding when a writing is integrated. These integration rules, however, are as dark and full of subtle difficulties as are other parts of parol evidence rules. As a way of thinking about Hanoch Dagan and Michael Heller's The Choice Theory of Contracts, this Article suggests we would do better with tailored integration rules for two transaction types. In negotiated contracts between firms, courts should apply a hard express integration rule, requiring firms to say when they intend a writing to be integrated. In consumer contracts, standard terms should automatically be integrated against consumerside communications, and never integrated against a business's communications. The argument for each rule rests on the ways parties make and express contractual choices in these types of transactions. Whereas Dagan and Heller emphasize the different values at stake in different spheres of contracting, differences among parties'capacities for choice - or the "mechanics of choice" - are at least as important.
\end{abstract}

\section{INTRODUCTION}

Contractual obligations are chosen obligations. They are chosen in two senses. First, each party must choose to enter into an agreement that generates the contractual obligations. Each must assent to the deal. Second, the parties have the ability to choose the terms of their agreement, and thereby determine the content of their contractual obligations. The parties can decide what the deal is.

* Agnes N. Williams Research Professor, Professor of Law, Georgetown University Law Center. This Article was presented at the Freedom, Choice, and Contract Conference, Columbia Law School, October 13-14, 2017, and benefited from the questions and feedback I received there.

Cite as: Gregory Klass, Parol Evidence Rules and the Mechanics of Choice, 20 Theoretical Inquiries L. 457 (2019). 
Many rules of contract law address how parties make those choices. Some of those rules are about parties' choice to enter into a legally binding agreement. These include rules governing offer and acceptance, implied-infact contracts, Statutes of Frauds, and formation defenses. Other rules are about how parties choose terms. Examples include hierarchies of interpretive evidence, plain meaning rules, default obligations, and contra proferentem. Taken as a whole, these rules do two things: they tell adjudicators how to decide whether and how parties have exercised their power to choose, and they inform sophisticated parties what they must do to exercise a legally effective choice.

This Article argues that contract theorists - scholars exploring the normative basis of contract law - should pay more attention to how contracting parties make choices and to how the law determines the choices they have made. Or as I put the point below, theorists should pay attention both to the mechanics of choice and to legal mechanisms for choosing. I make the case by exploring the relevance of both to Hanoch Dagan and Michael Heller's choice theory of contracts. ${ }^{1}$ Dagan and Heller argue that the core value of contract law is to enable party choice. Yet they pay little attention to the mechanics of choice or legal mechanisms for choosing. That neglect, I argue, renders their theory incomplete, and at times Panglossian.

I support that claim through a close examination of one mechanism of contractual choice: the parol evidence rule. When parties reduce their agreement to writing, courts sometimes treat that writing as dispositive of the terms in it, or even of the parties' agreement as a whole. In common law jurisdictions, the primary rule for determining when a writing is given special evidentiary weight is the parol evidence rule. The term "parol evidence" refers to evidence of the parties' agreement other than the writing at issue. A writing that operates to exclude parol evidence of terms is "integrated." Parol evidence rules determine when writings are integrated and when if ever parol evidence may be used to contradict, supplement, and sometimes interpret the terms contained in an integrated writing.

My analysis of parol evidence rules starts from Dagan and Heller's suggestion that we do better with different laws of contracts for different transaction types, or "spheres of contract." Examples of such spheres include agreements between firms, employment contracts, consumer contracts and intra-family agreements. I examine how, starting from a clean slate, we might design a parol evidence rule for each of two such spheres: negotiated contracts between firms and consumer contracts. Neither of the resulting parol evidence rules corresponds to the rules one finds in the case law or treatises. For negotiated

1 Hanoch Dagan \& Michael Heller, The Choice Theory of Contracts (2017). 
contracts between firms, the analysis suggests a hard, strict integration rule, requiring firms to say when they intend a writing to be integrated and treating such expressions as dispositive. For consumer contracts, I argue for automatic integration of standard terms against consumer-side parol communications together with a mandatory rule that standard terms are not integrated against a business's parol representations or promises. The argument for each rule relies in part on the social values at stake in each sphere. But the differences between the recommended rules reflect the different mechanics of choice in each - how in each sphere parties can and do exercise their power to choose terms. Whereas Dagan and Heller argue that local rules of contract law should be crafted in light of "the normative concerns driving different contract types," 2 this Article demonstrates that the mechanics and available mechanisms of choice are at least as important.

Along the way, this Article makes several other contributions. I reject the English Law Review Commission's argument that the parol evidence rule is not a separate rule of law, but a specific application of the general principles of contract law. I provide an analysis of parol evidence rules that emphasizes rules for integration, an oft overlooked element of those rules. I argue that contemporary formalist scholars have not been formalist enough in their thinking about integration in contracts between firms. And I suggest an argument for a largely choice-independent form of parol evidence rule for consumer contracts.

Part I introduces Dagan and Heller's choice theory, together with the ideas of the mechanics of choice and legal mechanisms for choosing. Part II provides an overview of existing parol evidence rules and the role of integration by way of a critical analysis of the English Law Review Commission's 1986 report on the rule. Part III argues that the mechanics of choice in two types of transactions, negotiated contracts between firms and consumer contracts, recommend different integration rules for each. The Conclusion draws a few lessons, both for Dagan and Heller's choice theory and contract theory more generally.

\section{The Choice Theory, the Mechanics of Choice, and Mechanisms for Choosing}

At least since the Legal Realists' attack on Langdell, English-language legal theorists have shown an affinity for lapsarian narratives. In The Choice Theory of Contract, Dagan and Heller blame contract law's fall from an earlier, more

$2 \quad I d$. at 7. 
Edenic state on Samuel Williston. Williston's original sin was to attempt to construct a unified theory of contract law, taking commercial contracts as the paradigm and ignoring the many differences in the laws that governed other types of transactions. "This distinctive, early twentieth-century American trajectory elevated commercial transactions to the core of contract, and, as a byproduct, substantially obscured the generative role of diverse contract types." 3 Dagan and Heller suggest that many contracts scholars remain captive to this Willistonian worldview, seeking out unifying principles and trying to craft rules of general applicability. ${ }^{4}$ In fact, Dagan and Heller argue, there are many different types, or "spheres," of contractual transactions. Examples include agreements between businesses of various types, employment relationships, consumer transactions, and agreements among family members. Because different spheres implicate different values, the law should not treat all alike. More specifically, the sometimes competing values of community and efficiency take on different forms and receive different weights depending on the sphere of contracting. A universal law of contract cannot take account of the specific mix of values at stake in each sphere. We should not, therefore, seek one big law of contract, but should construct local contract laws for the various spheres of contracting.

In addition to this intersphere legal pluralism, Dagan and Heller advocate for intrasphere pluralism of contract types and terms. No matter the social values at stake in one or another sphere, parties' autonomous choice should remain a guiding principle in all spheres. Party autonomy is valuable for at least two reasons. First, and most familiarly, autonomous choice is a good in itself. Second, party autonomy addresses the fact that even within a single

3 Dagan \& Heller, supra note 1, at 8. It is worth noting that Book V of the first edition of Williston's treatise, which occupies the bulk of Volume Two, was devoted to "Particular Classes of Contract." These included chapters on Contracts for the Sale of Land, Contracts for the Sale of Personal Property, Contracts of Employment and Contracts to Marry, Contracts of Bailment and of Innkeepers, Contracts of Affreightment, Bills of Exchange and Promissory Notes, and Contracts of Suretyship. 5 Samuel Williston, The LaW of Contracts $\S 633,1225$ (1924).

4 Dagan and Heller are not the first to suggest different contract laws for different spheres of contracting. See, e.g., William J. Woodward, Jr., "Sale" of Law and Forum and the Widening Gulf Between "Consumer" and "Nonconsumer" Contracts in the UCC, 75 WASH. U. L.Q. 243 (1997); Ethan J. Leib, On Collaboration, Organizations, and Conciliation in the General Theory of Contract, 24 Quinnipiac L. Rev. 1 (2005); Ronald J. Gilson, Charles F. Sabel \& Robert E. Scott, Text and Context: Contract Interpretation as Contract Design, 100 Cornell L. Rev. 23 (2014). 
sphere there is no one right way to balance competing values. Party choice provides a means of resolving conflicts between our normative commitments. ${ }^{5}$

Dagan and Heller suggest that the law should enable intrasphere choice in two ways. First, the law should ensure that within any given sphere there is a choice among "contract types" - pre-established or off-the-rack transaction structures. ${ }^{6}$ Predefined contract types promote efficiency by reducing transaction costs. But they do more than that. Contract types also enhance autonomy by providing socially recognized relational forms that embody various mixes of values and shared cultural meanings, thereby generating new meaningful forms of acting together. ${ }^{7}$ Second, autonomy requires also that the parties be granted the power to make alterations to the off-the-rack contract types society offers. A commitment to voluntariness "implies that people should generally be able to choose not only among various contract types, but also terms within each."

Although Dagan and Heller say a lot about the value of choice, they do not say much about how parties make such choices. There are two salient dimensions to how contracting parties exercise their powers of choice. The first is parties' baseline abilities to choose, and the conditions under which they are able to make informed, autonomous and therefore valuable choices. I will call this the "mechanics of choice."

Although Dagan and Heller do not spend many pages on the topic, they do not ignore the mechanics of choice. For example:

Sometimes, cognitive, behavioral, structural, and political economy reasons imply that more choice may actually reduce freedom. But those circumstances will be local to certain contract types or market structures, not universal to contract as a whole. Frankly, we just don't know in which contexts the probable effects of these concerns are significant enough to justify limiting multiplicity. ${ }^{9}$

5 DAGAN \& Heller, supra note 1 , at 80.

$6 \quad I d$. at 3.

7 Id. at 76 ("[W]hen contract law offers us multiple contract types, it participates in the ongoing social production of stable categories of human interaction by consolidating people's expectations of themselves and others. In this, law enlarges the range of valuable options available to us.").

$8 \quad I d$. at 109.

9 Id. at 127. See also id. at 74 ("The impediments to secure contracting often depend on the specific features of the particular contract type and therefore each type requires its own legal facilitation."), 106-07 (suggesting that how people choose and the design of choice mechanisms "should be . . . a major focus of behavioral and institutional economics studies of contract law"). 
Dagan and Heller also argue that the mechanics of consumer choice suggest mandatory restrictions on businesses' ability to include hard-to-read terms like arbitration clauses or class-action waivers. "[C]hoice theory implies that [these terms'] inclusion in consumer contracts should not be able to upset consumers' background expectation of relatively unimpeded access to courts or to reasonably equivalent procedures for dispute resolution." 10

Dagan and Heller have less to say about a second dimension of how parties choose, which I will call the "mechanisms of choice." These are the tools that the law gives parties for exercising their power to choose, which Ian Ayres has called "altering rules." Heller's positive view of section 17.42 of Texas's Deceptive Trade Practices and Consumer Protection Act, which empowers consumers to waive the Act's protections. ${ }^{12}$ Dagan and Heller favor the opt-out provision, as "people should, in some circumstances, be able to choose between purchasing a good with the protections of consumer transaction law or by using sales law."13 They do not discuss, however, what a consumer must do to opt out of such protections - the mechanisms needed to ensure a fully informed and valuable choice.

It is worth paying attention to those details. Section 17.42 requires that "(1) the waiver is in writing and is signed by the consumer; (2) the consumer is not in a significantly disparate bargaining position; and (3) the consumer is represented by legal counsel in seeking or acquiring the goods or services." 14 It requires that the consumer's counsel be independent of the business. And it requires that the waiver be:

(1) conspicuous and in bold-face type of at least 10 points in size; (2) identified by the heading "Waiver of Consumer Rights," or words of similar meaning; and (3) in substantially the following form: "I waive my rights under the Deceptive Trade Practices-Consumer Protection Act, Section 17.41 et seq., Business \& Commerce Code, a law that gives consumers special rights and protections. After consultation with an attorney of my own selection, I voluntarily consent to this waiver." 15

$10 \quad$ Id. at 112.

11 Ian Ayres, Regulating Opt-Out: An Economic Theory of Altering Rules, 121 YALE L.J. 2032 (2012).

12 Tex. Bus. Com. Code Ann. § 17.42 (West 2017).

13 DAGAN \& HELLER, supra note 1, at 71. See also id. at 82 (advocating that consumers be able to "make their own (individual) choices between the 'souk' or 'bazaar' mode of 'as is' contracting and the 'errands' model of consumer protection law").

14 Tex. Bus. Com. Code Ann. $§$ 17.42(a) (West 2017).

15 Id. at $\S \S 17.42$ (b) \& (c). 
This choice mechanism makes perfect sense given the mechanics of consumer choice - the difficulty of ensuring informed consumer agreement to a term such as this. The Texas legislature appears to have been concerned that a consumer might assent to waive the Act's protections without fully understanding what she was giving up, as consumers regularly assent to unread standard terms. The resulting mechanism of choice, however, is enormously expensive to use. One might guess that few if any Texans will exercise this power of choice the Texas legislature has granted them.

The remainder of this Article examines one of the most important mechanisms of choice in U.S. contract law: parol evidence rules. A parol evidence rule provides mechanisms of contractual choice in two ways. First, if a writing is integrated, the rule limits the evidence an adjudicator may consider when deciding what terms parties have chosen. In this way, parol evidence rules determine how parties can exercise their legal power to choose terms: sometimes they must express that choice in a writing. Second, modern parol evidence rules treat integration as itself a matter of choice: A writing is integrated only if the parties have agreed that it shall be a final statement of some or all terms of their agreement. U.S. courts have crafted several rules for deciding when parties have made that choice. That is, they have provided parties with various mechanisms for exercising the choice to integrate a writing.

It is widely recognized that different U.S. jurisdictions employ different parol evidence rules. Most accounts of those rules, however, describe one parol evidence rule for all contracts. Dagan and Heller's choice theory suggests a different approach. Perhaps there is not, or should not be, one big parol evidence rule, but local parol evidence rules for distinct spheres of contracting. Part III explores that idea, focusing on two spheres of contracting: negotiated contracts between firms and consumer contracts. Before getting there, however, it is necessary to say a few words about parol evidence rules generally.

\section{Parol Evidence Rules: The Basics}

It is no easy thing to summarize the parol evidence rules found in the common law of contracts. The reasons are manifold. Parol evidence rules are complex, with multiple moving parts. Judicial articulations of the rules often bear traces of older doctrines modern rules were meant to supplant. There are important differences between parol evidence rules in different jurisdictions, and often among articulations of the rule in a single jurisdiction. And applications of the rules often involve fact-specific judgments that make it difficult to draw broad conclusions from individual holdings. This Part nonetheless attempts to provide a basic introduction. I distinguish three core elements of 
parol evidence rules, which I call the "terms component," the "interpretive component," and the "integration component." The focus of this Article is on the integration components of U.S. parol evidence rules. I provide an analysis of integration rules generally by way of a critical examination of the English Law Commission's 1986 report on the parol evidence rule.

All modern parol evidence rules share a basic structure. A finding that a writing is integrated limits, in one way or another, the evidence an adjudicator may consider to determine the content of the parties' agreement. A partially integrated writing excludes parol evidence of terms contrary to those in the writing; a completely integrated writing excludes parol evidence of terms contrary or in addition to those in the writing. ${ }^{16}$ I call this the "terms component" of a parol evidence rule, as it cuts off evidence of contrary or additional terms. Some courts and commentators have suggested that integration should also limit the types of evidence an adjudicator may consider when interpreting the words in the writing. ${ }^{17}$ More specifically, they have argued that except in cases of ambiguity, the words in an integrated writing should be interpreted according to their plain meaning, without the aid of extrinsic evidence. I call this the "interpretive component" of a parol evidence rule. The details of both terms components and interpretive components of parol evidence rules differ across U.S. jurisdictions. ${ }^{18}$

Interesting and important as these sub-rules are, I want to focus on a third component of parol evidence rules: the rule for determining whether a contractual writing is integrated, and if so, whether partially or completely. I will call this the "integration component" or "integration rule."

There is today broad agreement that a writing is integrated if and only if the parties together intended that it would serve a final statement of some or all terms of their agreement. ${ }^{19}$ As Williston put the point, "The parol evidence

16 Restatement (Second) of Contracts $\S \S 215-16$ (Am. Law Inst. 1981).

17 This position is often associated with Williston. See 2 WiLliston, supra note 3 , at $\S \S 604,605 \& 607,1162-64,1167-71$ (advocating different standards of interpretation for informal contracts and integrated writings).

18 See 2 E. Allan Farnsworth, Farnsworth On Contracts $§ 7.3,218-19$ (3d ed. 2004) (discussing the meaning of "consistent" in the parol evidence rule); $i d$. at $\S 7.12,292-304$ (discussing judicial approaches to interpreting integrated agreements).

19 Among U.S. scholars, the claim dates back at least to Wigmore, who emphasized that the integration question "is a question of the nature of the act and of the party's intention to embody it solely in the writing." 4 John Henry Wigmore, A Treatise on the System of Evidence in Trials at Common LaW $§ 2427,3423$ (1905). Judicial expressions of the idea can be found even earlier. Thus in an 1859 case in the Court of the Exchequer, Lord Pollock held that the defendant 
rule does not apply to every contract of which there is written evidence, but only applies where the parties to an agreement reduce it to writing, and agree or intend that that writing shall be their agreement." ${ }^{20}$ Similarly for Arthur Corbin, a writing is integrated when the parties "have both assented [to it] as the complete and accurate integration of that contract." ${ }^{.1}$ Integration, everyone today concurs, is a matter of party agreement.

In a 1986 report on the parol evidence rule, the English Law Review Commission suggested that it follows from the agreement-based understanding of integration that there is in fact no such thing as a parol evidence rule.

[A]lthough a proposition of law can be stated which can be described as the "parol evidence rule" it is not a rule of law which, correctly applied, could lead to evidence being unjustly excluded. Rather, it is a proposition of law which is no more than a circular statement: when it is proved or admitted that the parties to a contract intended that all the express terms of their agreement should be recorded in a particular document or documents, evidence will be inadmissible (because irrelevant) if it is tendered only for the purpose of adding to, varying, subtracting from or contradicting the express terms of a contract. We have considerable doubts whether such a proposition should properly be characterized as a "rule" at all. ${ }^{22}$

If integration is merely one contract term among others, then what has traditionally been called the "parol evidence rule" is in fact no more than a specific application of general principles of contract law. It is not the existence of the writing that matters, but the content of the parties' agreement, as with any other contract term. "The conclusion which emerges ... [i] that there is no rule of law that evidence is rendered inadmissible or is to be ignored solely because a document exists which looks like a complete contract. Whether it

could introduce parol evidence that a bill of sale had been given as security for an earlier loan, reasoning:

The jury have found that it was agreed to give the bill of sale; they have not found, nor does it appear to us, that the writing was intended to contain the whole agreement, and we are of opinion that the rule relied on by the plaintiffs only applies where the parties to an agreement reduce it to writing, and agree or intend that that writing shall be their agreement.

Harris v. Rickett (1859) 157 Eng. Rep. 734, 737.

202 Williston, supra note 3 , at $\S 633,1225$.

21 Arthur L. Corbin, The Parol Evidence Rule, 53 Yale L.J. 603, 603 (1944).

22 Law Commission, Law of Contract: The Parol Evidence Rule, 1986, Cmnd. $9700, \S 2.7$, at 8 (UK) (emphasis in the original, footnotes omitted). 
is a complete contract depends upon the intentions of the parties, objectively judged, and not on any rule of law." ${ }^{23}$

The Law Commission's reasoning is flawed. An agreement-based understanding of integration does not entail that there is no parol evidence rule - that anything we might call "the parol evidence rule" is just a specific application of general principles of contract law. There are at least three reasons why this is so. Identifying them will provide a more nuanced understanding of the nature of integration rules and how they function as mechanisms of choice.

First, the fact that parties have the power to contract for one or another type of term is not a given, but is itself a rule of law. Contract law sets a host of mandatory limits on parties' ability to contract. A contract for murder will not be enforced. An employer and employee do not have the power to contract for a salary below the minimum wage, or to contract out of safety or antidiscrimination laws. A landlord and residential tenant do not have the power to contract out of the implied warranty of habitability. The power to contract for one or another term is not a given. It exists because the law grants persons that power.

This is all the more so with respect to a term like integration. Many contract terms specify first-order obligations - obligations whose nonperformance would constitute a breach ${ }^{24}$ When parties agree to integrate a writing, however, they are doing something very different. Rather than undertaking new obligations, they are agreeing to alter the rules that govern how their obligations will be determined. Integration is a framework term, comparable to a choice of law clause, a liquidated damages clause, or an arbitration clause. Framework terms do not specify the parties' first-order performance obligations, but determine how those obligations can be undertaken, how they will be construed, the consequences of their breach, who will adjudicate disputes, and the like..$^{25}$

The point of noticing this difference is that the reasons for extending freedom of contract with respect to first-order terms need not apply pari passu to framework terms. Limits on parties' ability to contract for first-

\section{$23 I d$. at $\S 2.16,13$ (emphasis in the original).}

24 In addition to first-order obligations, a contract might provide for first-order permissions, powers and other jural relations. I ignore these additional types of contract terms only for the sake of simplicity.

25 My distinction between first-order and framework terms is comparable to Jody Kraus and Robert Scott's between parties' contractual ends - the parties' proximate reasons for entering into the transaction - and their contractual means - the legal tools parties use to accomplish those ends. Jody S. Kraus \& Robert E. Scott, Contract Design and the Structure of Contractual Intent, 84 N.Y.U. L. REV. 1023, 1026 (2009). 
order obligations are often reasonably described as one or another form of parentalism. Limits on parties' ability to contract for alternative framework rules - such as rules governing the evidence a court will consider to determine just what the parties agreed to - are more likely to reflect the social interests in enforcement, interests that individual parties do not get to decide.

It is not difficult to imagine a legal world in which contracting parties do not have the power to specify a writing's evidentiary value. Tort law does not give parties the power to determine what evidence of fraudulent misrepresentation a court may consider. ${ }^{26}$ Everything always counts. At the other end of the spectrum, the law of wills mandates that the only words that matter when determining a decedent's bequests are those contained in her properly executed last will and testament. ${ }^{27}$ Only the writing counts, no matter what the testator might say. And prior to the emergence of agreementbased parol evidence rules, the best evidence rule automatically excluded oral evidence of terms contrary to those in contractual writings, without giving parties the ability to choose otherwise. ${ }^{28}$ The parol evidence rule does not simply flow from general principles of contractual freedom. It represents a legal decision to grant to parties the power to determine a writing's legal effects. That makes it a rule of law.

The second error in the Law Commission's reasoning is its failure to recognize that the legal effects of an agreement to integrate might extend beyond the content of that agreement. ${ }^{29}$ The existence of both a terms component and an interpretive component in U.S. parol evidence rules illustrates the idea. An agreement to integrate is an agreement that a writing shall be the final statement of some or all terms. It is an agreement to the terms component.

26 See Kevin Davis, Licensing Lies: Merger Clauses, the Parol Evidence Rule and Pre-Contractual Misrepresentations, 33 Val. U. L. ReV. 485 (1999).

27 Wigmore, who was one of the first to formulate the agreement-based integration rules for contractual writings, emphasized that wills and several other types of writings were integrated as a matter of law. See Wigmore, supra note 19, at $\S$ 2452, 3461-63.

28 The best evidence rule established an evidentiary hierarchy: written evidence, which was commonly under seal, could not be contradicted by oral evidence. See generally John William Salmond, The Superiority of Written Evidence, 6 LAW Q. REv. 75 (1890).

29 This is an example of the importance of attending to the distinction between the interpretation of a contractual agreement - determining its meaning - and the construction of that agreement - determining its legal effect. See Gregory Klass, Contracts, Constitutions, and Getting the Interpretation-Construction Distinction Right, 18 Geo. J. L. \& PuB. PoL'y (forthcoming 2019), https://ssrn. com/abstract $=3347122$. 
The agreement to integrate might also, however, trigger a plain meaning rule of interpretation - whether or not the parties have agreed to that interpretive component. The interpretive rule results from the parties' agreement to integrate, but might not be something the parties agreed to.

One might respond to the above point by arguing that interpretive components of parol evidence rules are designed to capture how most parties expect or want their integrated writing to be interpreted, and therefore are also agreementbased. Williston, for example, argues that a plain meaning rule reflects how most parties think about an integrated writing.

In an ordinary oral contract or one made by correspondence, the minds of the parties are not primarily addressed to the symbols which they are using; they are considering the things for which the symbols stand. Where, however, they incorporate their agreement into a writing they have attempted more than to assent by means of symbols to certain things, they have assented to the writing as the adequate expression of the things to which they agree. ${ }^{30}$

If most parties who produce integrated writings expect or prefer that those writings be interpreted according to their plain meaning, then a plain meaning interpretation component is designed in a way to capture their intentions or agreement.

The above response misses the mark. Plain meaning interpretive components are default rules. ${ }^{31}$ They do not require that parties actually agree that the writing will be interpreted according to its plain meaning, but automatically attach that consequence to the parties' agreement that the writing serve as a final statement of terms. It might well be that the interpretive components of some parol evidence rules are designed to effectuate what most parties would agree to if they considered the issue. But the resulting interpretive rule is not a product of the parties' agreement to it.

I do not want to overstate the claim here. A parol evidence rule need not include an interpretive component. ${ }^{32}$ In fact, in its 1986 Report the Law

302 Williston, supra note 3 , at $\S 606,1165$.

31 "Default rules" because parties could presumably contract out of plain meaning interpretation by expressing their intention that the agreement be interpreted in light of the surrounding context. Such clauses are rare, but not unheard of. In Corthell v. Summit Thread Co., for example, the Maine Supreme Court considered an employment agreement that "specified that the terms of the contract were to be interpreted in good faith on the basis of what is reasonable and intended, and not technically." Corthell v. Summit Thread Co., 167 A. 79, 80 (Me. 1933).

32 There is some confusion among authorities on the interpretive component of U.S. parol evidence rules. In the first edition of his treatise, Williston advocated 
Commission rejected the idea that under English law integrated writings were subject to separate rules of interpretation. ${ }^{33}$ So with respect to English law, the Law Commission may be correct on this issue. But the broader point remains: the legal effects of an agreement to integrate need not be identical to the content of that agreement. Where they are not, a parol evidence rule is not merely an application of the general principles of contract law.

Third, and most significantly for my purposes, if integration is a matter of agreement there must also be a legal rule for how parties can or must express their agreement to integrate for it to be legally effective. ${ }^{34}$ That is, an agreement-based parol evidence rule must include a mechanism of choice.

U.S. courts recognize two ways parties can effectively express or evince their shared intent to integrate. First, parties can include in the writing an integration clause. An integration clause states that the writing is the final statement of some or all terms. For example:

This instrument embodies the whole agreement of the parties. There are no promises, terms, conditions, or obligations other than those contained in this contract, and this contract shall supersede all previous communications, representations, or agreements, either verbal or written, between the parties. ${ }^{35}$

a plain meaning rule for integrated agreements. See 2 Williston, supra note 3 , at $\S 606,1164-67$. Corbin rejected that interpretive rule on the theory that meaning can never be plain except in context. See 3 Arthur Linton Corbin, Corbin on Contracts: A Comprehensive Treatise on the Rules of Contract LAW $\S 536,27-28$ (1951); Arthur L. Corbin, The Interpretation of Words and the Parol Evidence Rule, 50 CORNELL L.Q. 161, 173 (1965) [hereinafter Corbin, The Interpretation of Words]. Section 212 of the Second Restatement adopts something like a middle path. Section 212(1) suggests no plain meaning rule: "The interpretation of an integrated agreement is directed to the meaning of the terms of the writing or writings in the light of the circumstances." Section 212(2), however, specifies that in the absence of ambiguity, meaning is to be decided by the court. Restatement (SECOND) of Contracts $§ 212$ (Am. LaW InSt. 1981). Farnsworth argues that this is still a plain meaning rule, as it involves a two-step process: first deciding whether there is an ambiguity (under the Restatement, in light of all the evidence) and, if there is no ambiguity, a judicial decision based on the writing's plain meaning. 2 FARNSWORTH, supra note 18, at $\S 7.12,314-15$.

33 LaW COMmission Report, supra note 22 , at $\S \S 1.2 \& 2.7,2 \& 8$.

34 Putting the question in these terms clarifies that the parol evidence rule also includes a default. According to the blackletter law, the generic default is that a writing is not integrated.

35 IA Samuel Williston, A Treatise on the Law of Contracts: Forms $§ 33 \mathrm{~F}: 2$, 170 (4th ed. 1990). 
I will call this the "express prong" of U.S. integration rules. Second, if the writing contains no integration clause, a court will look to whether it appears to be intended as a final statement of some or all terms. "Where the parties reduce an agreement to a writing which in view of its completeness and specificity reasonably appears to be a complete agreement, it is taken to be an integrated agreement. ${ }^{" 36}$ I will call this the "implied prong." Just as a contractual agreement can be either express or implied-in-fact, so an agreement to integrate can be either express or implied. A writing that contains an integration clause is expressly integrated. When the parties have not expressed their agreement to integrate in words, but the character of the writing indicates such an agreement, the writing is impliedly integrated.

Although U.S. courts broadly agree on the two prongs of the integration rule, they differ on what evidence a decision maker may consider when determining the parties' intent to integrate. The integration components of more formalist, or "harder," parol evidence rules - often associated with Williston - provide that if the writing appears on its face intended to be a final statement of some or all the parties' obligations, it is integrated.$^{37}$ That is, a writing alone can suffice to demonstrate its integration, even if there exists contrary parol evidence. Extrinsic evidence of the parties' intent vel non to integrate is admitted only if the writing alone does not answer the question. The integration components of less formalist, or "softer," parol evidence rules - associated with Corbin - are quicker to permit extrinsic evidence. The decision maker should always consider all available evidence of the parties' intent, even if the writing appears to be integrated - in fact, even if it includes an integration clause. ${ }^{38}$ The Second Restatement adopts Corbin's approach: "A writing cannot of itself prove its own completeness." 39

The current edition of Williston's treatise acknowledges that the Second Restatement adopts a soft integration rule, but reports that the majority rule is

36 Restatement (Second) of Contracts $§$ 209(3) (Am. Law Inst. 1981).

37 "[T] he contract must appear on its face to be incomplete in order to permit parol evidence of additional terms." WiLLISTON, supra note 3, at $§ 633,1226$.

38 "If the offered evidence is relevant and credible on the issue of ... . integration, it should never be excluded, for the reason that, whatever are the written words, those issues are always debatable." Corbin, The Interpretation of Words, supra note 32, at 173. See also Corbin, supra note 21, at 642 ("Just as no written document can prove its own execution, so none can prove that it was ever assented to as either a partial or a complete integration, supplanting and discharging what preceded it.").

39 Restatement (Second) of Contracts $§ 210$ cmt. b (Am. Law Inst. 1981). 
a hard one..$^{40}$ The most recent edition of E. Allan Farnsworth's treatise, on the contrary, suggests that "the prevailing view [is] that other evidence, including evidence of prior negotiations, is still admissible to show that a writing was not intended as a final expression of the terms it contains." ${ }^{41}$ Under either rule, extrinsic evidence may be introduced to show an invalidating cause such as misrepresentation, duress or mistake.

To summarize this third point, the express and implied prongs identify two ways parties can effectively express their intent to integrate. Hard or soft evidentiary rules further specify what evidence courts may consider when determining whether the parties have satisfied one or the other prong..$^{42}$ Pace the Law Commission Report, none of these rules can be deduced from the general principles of contract law. They govern what parties must say or do to achieve a specific legal outcome: an integrated writing. They are legally established mechanisms of integration.

The Law Commission was therefore wrong to conclude that because integration is a matter of agreement, the so-called parol evidence rule is not a distinct rule of law. First, it is not a given that parties should have the power to determine a writing's legal effect. The fact that the law grants them that power is itself a substantive rule. Second, depending on the jurisdiction, integration can also have legal effects that extend beyond the content of the parties' agreement. An agreement that the writing shall be a final statement of terms might trigger a plain meaning rule, a legal effect that does not stem from the parties' agreement. Third, parol evidence rules commonly specify not only that parties have the power to integrate a writing by agreement, but also how they can effectively express their agreement to integrate, and what evidence legal decision makers may consider when determining whether the parties have reached such an agreement. These legally determined mechanisms of choice are again more than local applications of general contract principles.

\section{Integration Rules and Spheres of Contracting}

The above discussion follows the vast majority of judicial statements and scholarly discussions by treating the parol evidence rule as one rule for all contractual agreements. It also identifies, however, some of the design decisions

40 11 SAmuel Williston, supra note 35, at $\$ 33: 17,969-74$ ("Evidence on the issue of whether an integration exists; traditional and modern views.").

41 FARNSWORTH, supra note 18, at $§ 7.3,227$.

42 An even more complete and complex description of integration rules would also discuss the fact that there are rules for both partial and complete integration, and that these might differ from one another. 
that go into a parol evidence rule. Parol evidence rules do not simply flow from general principles of contract law. The fact that parties have the power to integrate a writing, the legal effects of integration, and the rules for how parties can exercise the power to integrate each represent a design choice. That, in turn suggests the possibility of designing different parol evidence rules - and particularly different integration rules — for different spheres of contracting.

There is some evidence that courts already apply the parol evidence rule differentially depending on who the parties are or the type of transaction they are engaged in. In 1972, Robert Childres and Stephen Spitz reported a study of 149 cases in which they found courts more likely to apply the rule strictly to contracts between parties with some expertise and business sophistication, and less likely to apply it strictly to contracts between parties lacking such sophistication..$^{43}$ And though not a comparative study, the Reporters for the American Law Institute's draft Restatement of the Law of Consumer Contracts state that they find the vast majority of courts applying a soft parol evidence rule to consumer contracts - holding that a presumption of integration is rebuttable, whether or not the writing contains an integration clause. ${ }^{44}$

This Part argues that there are good reasons to adopt different parol evidence rules for different spheres of contracting. I discuss two spheres: negotiated contracts between firms and consumer contracts. The method is top down. Rather than look at how courts in fact apply the rule in each of these spheres, I ask what rule they should apply. I begin by describing the social values at stake and the mechanics of consent in each sphere. I then ask what parol evidence rule would best serve those values given those mechanics, paying particular attention to the mechanisms of choice for integration - in other words, the integration components of the rules. (I do not address other design questions, such as the best rule for determining when a parol term is contrary to those in the writing, or whether the parol evidence rules for such transactions should include interpretive components.) This analysis suggests parol evidence

43 Robert Childres \& Stephen J. Spitz, Status in the Law of Contract, 47 N.Y.U. L. Rev. 1 (1972). See also Michael A. Lawrence, Comment, The Parol Evidence Rule in Wisconsin: Status in the Law of Contract, Revisited, 1991 WIs. L. REv. 1071 (replicating Childres and Spitz's results with a set of Wisconsin cases decided between 1980 and 1991).

44 Restatement of the Law, Consumer Contracts $\S 8$ Reporters' Notes, at 94-96 (Am. Law Inst., Discussion Draft No. 4, 2017) (hereinafter "Draft Consumer CONTRACts RestatemenT"). For some concerns about the empirical methods used in the draft Restatement, see Gregory Klass, Empiricism and Privacy Policies in the Restatement of Consumer Contract Law, 36 YALE J. REG. 45 (2019). 
rules for these spheres that significantly differ from the common generic formulations of the rule, and from one another. ${ }^{45}$

\section{A. Negotiated Contracts Between Firms}

Consider first transactions in which two large firms negotiate the details of a high-value exchange. To keep things simple, I will help myself to Alan Schwartz and Robert Scott's description of such exchanges. ${ }^{46}$ Whether or not correct in all its details, their account provides a useful model to work with.

The transactions Schwartz and Scott analyze have three salient characteristics. First, both parties are sophisticated, meaning that each has the knowledge and reasoning capacity to identify the terms that best serve its interests. "Firms and markets are structured so as to minimize the likelihood of systematic cognitive error by important decision makers within the firm." ${ }^{47}$ Second, a firm's primary goal is to maximize shareholder returns, which it achieves by maximizing its own profits. ${ }^{48}$ Third, in a transaction between two firms, the way each maximizes its individual profit is by maximizing the joint surplus, which will be split between them according to each firm's exogenously determined bargaining power. ${ }^{49}$ In addition to these three features, I will limit my analysis to contracts in which a significant number of terms have been negotiated. This excludes, for example, an adhesive end-user license agreement that might exist between two firms by virtue of an employee's decision to update a software package. I am interested in written agreements that both sides have read and understood. This is the case when firms have negotiated a significant number of terms.

I am also going to help myself to Schwartz and Scott's thesis that society enforces agreements between firms for the same reasons firms enter into

45 Eric Posner has also recommended a tailored parol evidence rule. But he considers only the decision between hard and soft versions of the rule. "[W]hen contracts are conventional and complex, soft-PER is optimal .... When contracts are unconventional and simple, hard-PER is optimal." Eric A. Posner, The Parol Evidence Rule, the Plain Meaning Rule, and the Principles of Contractual Interpretation, 146 U. PA. L. REv. 533, 553 (1998).

46 Alan Schwartz \& Robert E. Scott, Contract Theory and the Limits of Contract Law, 113 Yale L.J. 541 (2003).

47 Id. at 545-46. Schwartz and Scott suggest the following rough-and-ready rule for which firms meet this description: "(1) an entity that is organized in the corporate form and that has five or more employees, (2) a limited partnership, or (3) a professional partnership such as a law or accounting firm."

48 Id. at 550-51.

49 Id. at 549. 
them, namely, to secure the greatest gains of trade possible. ${ }^{50}$ Society does not enforce agreements between firms because, for example, such agreements generate a moral obligation to perform, because their breach creates a moral obligation to compensate, or because they generate intrinsically valuable relationships or forms of community. Society enforces them because doing so increases overall welfare.

This similarity between society's reasons for enforcing firm-to-firm agreements and firms' reasons for entering into them, together with the assumption that firms are sophisticated in the sense defined above, entails that when firms pursue their own ends they will choose contract terms that also advance society's reasons for enforcing their contracts. Contract law should therefore be designed, generally speaking, to give firms both the first-order and the framework terms that they want; hence the observed congruence between efficiency and autonomy theories of contract law. ${ }^{51}$

All this provides support for an agreement-based parol evidence rule for contracts between firms. In this sphere and under the above assumptions, we should want courts to treat a writing as integrated if and only if the parties intended it to be a final statement of some or all terms. What this means at the design level is crafting an integration rule that gives firms maximal power to determine when a writing is integrated. Contract law should provide firms a cheap, fast and predictable mechanism for determining a writing's legal effects. ${ }^{52}$

It is odd that U.S. law does not give sophisticated parties a formality to signal their intent to integrate. The parol evidence rule confers on parties a legal power. It enables them to determine a writing's legal effects by expressing their shared intent that it serve as a final statement of terms. A short, canonical form with which to express that intent would be extremely useful. Karl Llewellyn, no advocate of formalism writ large, recognized that "a business economy demands a means of quick, not one of 'informal' contracting." ${ }^{53}$ Although

$50 I d$. at 546 (arguing that it is futile "to pursue either distributional goals or contractual fairness" in contracts between firms, as "firms will contract away from redistributive or fair legal rules that do not maximize joint surplus").

51 E.g., Charles Fried, The Ambitions of Contract as Promise, in Philosophical Foundations of Contract Law 17, 21-24 (Gregory Klass, George Letsas, \& Prince Saprai eds., 2014).

52 The following analysis assumes that the default is that a writing between firms is not integrated. This is the current rule, and makes a fair bit of sense. Firms produce many writings during the course of negotiations. It would be strange to expect them to say for each one that it is not intended to be a final statement of terms.

53 Karl N. Llewellyn, What Price Contract? - An Essay in Perspective, 40 Yale L.J. 704, 741 (1931). Llewellyn pointed to empirical evidence in support: 
form books are full of model integration clauses, there exists in U.S. law no canonical formula, comparable to "F.O.B." or "as is," that parties can use to integrate a writing. The seal once served something like that function, and still does in some jurisdictions. But the seal was always a blunt instrument, as putting a writing under seal had other legal effects as well. ${ }^{54}$ A legally efficacious formality — such as printing the words "Legally Operative Statement of All Terms" or "Legally Operative Statement of Included Terms" at the top of a document - would provide parties who wish to integrate the writing a useful tool for doing so. The fact that U.S. law includes no such formality is a historical accident, perhaps attributable to a general movement away from formalities in the early twentieth century, the period during which the modern, agreement-based parol evidence rule came into existence.

Given that U.S. law does not include an integration formality, what should the integration rule for negotiated contracts between firms be? Recall that integration rules in U.S. jurisdictions have two prongs. To satisfy the express prong, the parties must include in the writing an integration clause; to satisfy the implied prong, it must appear from the writing as a whole that the parties intended it as a final statement of some or all terms.

An express integration rule provides firms a cheap and certain means of effectively expressing their intent to integrate. If two firms negotiate a writing that includes an integration clause, courts should at least presumptively treat the writing as integrated. The only question is whether they should consider extrinsic evidence that might suggest a contrary result — whether the express prong should be a hard or soft rule.

A number of efficiency-minded scholars have applied cost-benefit analysis to argue that sophisticated parties prefer textualist interpretive approaches generally. ${ }^{55}$ Under the above assumptions, cost-benefit analysis is appropriate

"[W]hen we see the great exchanges devising means for exchanging written and signed memoranda of sales of grain and stocks - and, so far as an outsider can determine, profiting by the necessity - the notion that speed requires utter informality loses cogency." Id. at 740. See also Richard Craswell, Offer, Acceptance and Efficient Reliance, 48 StAN. L. REV. 481, 544-53 (1996).

54 Llewellyn makes this point too, arguing that the problem with the seal as not the seal itself, but "the persistence of archaic and arbitrary incidents in promises effective purely through their ancient form." Llewellyn, supra note 53, at 739.

55 See, e.g., Craswell, supra note 53, at 544-53; Kraus \& Scott, supra note 25; Posner, supra note 45; Schwartz \& Scott, supra note 46; Robert E. Scott, The Case for Formalism in Relational Contracts, 94 Nw. U. L. Rev. 847 (2000); Robert E. Scott, Text versus Context: The Failure of the Unitary Law of Contract Interpretation, in The American Illness: Essays on the Rule of LaW 312, 32124 (F.H. Buckley ed., 2013). 
in this sphere, for by maximizing joint gains, cost-benefit analysis advances both the goals of firms and the goals of society in enforcing their agreements. If these writers are correct, it follows that firms are better served by a hard express integration prong.

Avery Katz has argued that such cost-benefit arguments for textualism writ large are more difficult than commonly assumed. The problem is that we lack good empirical data about key variables..$^{56}$ These include the relative costs of drafting and of adjudication under various rules, parties' responsiveness to legal rules of construction, the accuracy gains that can be expected from permitting extrinsic evidence of meaning, and whether permitting extrinsic evidence makes outcomes more or less predictable. I agree with Katz that we lack the empirical data to know whether textualism is more efficient generally. But I believe the cost-benefit analysis is more tractable for a narrower question: Should courts consider extrinsic evidence when construing an integration clause in a negotiated writing between firms? To keep things relatively simple, I focus on four variables: (1) interpretive accuracy, or how likely a third-party adjudicator's interpretation is to match the parties' actual agreement; (2) costs of drafting; (3) costs of adjudication; and (4) predictability of outcomes. ${ }^{57}$

In negotiated transactions, both parties have taken some care to read the writing. And if both parties are firms, in the sense defined above, they have understood it. Absent fraud, duress or some other invalidating cause, the existence of an integration clause is therefore extremely strong evidence that the parties intended the writing to be a final statement of terms. Neither firm is likely to have agreed to the language by mistake. Nor are courts likely to

56 Avery Weiner Katz, The Economics of Form and Substance in Contract Interpretation, 104 CoLuM. L. REv. 496, 538 (2004) ("[T] he traditional scholarly approach to form and substance founders on a lack of information about the likely consequences of formal and substantive modes of interpretation."). A natural solution in such circumstance is to let sophisticated parties decide for themselves, on the assumption that they generally know more than lawmakers do about which framework rules serve their interests. That solution is not available, however, for the integration rule - which is in part a rule for deciding how the parties have decided which interpretive approach they prefer. Even if we want to allow parties to choose how their choices are to be interpreted, we still need a rule for determining when and how they have exercised that choice.

57 I am using "interpretive accuracy" to refer both to the absence of adjudicative error - when a court misreads the parties' expressed intent — and to the absence of party error - when the parties fail to express themselves as the legal rule requires for their desired result. For other lists of relevant factors, see Alan Schwartz \& Robert E. Scott, Contract Interpretation Redux, 119 YALE L.J. 926, 941 (2010); Katz, supra note 56, at 522-36; Posner, supra note 45, at 543-47. 
mistake an integration clause's meaning — the legal effect the parties intend. Permitting extrinsic evidence of the parties' intent to integrate would therefore result in few gains in accuracy. It is true that excluding such evidence might cause some parties to invest more at the drafting stage, so as to ensure that the integration clause unambiguously expresses their intent to integrate (costs a canonical formality would reduce). But there exist many form clauses to copy and paste, and any increase in drafting cost is likely offset by the advantage of lower adjudication costs, greater accuracy and greater predictability. With respect to express integration between firms, then, the largest gains come from excluding extrinsic evidence of the parties' intent to integrate, except when introduced to show fraud, duress or some other invalidating cause.

All this suggests a hard express integration rule for firm-to-firm negotiated contracts: A writing is integrated if it includes an integration clause, regardless of any extrinsic evidence to the contrary. What about when the writing does not include an integration clause? Should the integration rule for negotiated contracts between firms also include an implied prong?

There is a good argument that, on the above assumptions, implied integration is out of place in contracts between firms. The law does not recognize implied arbitration, implied damage limitation, implied no-modification or implied anti-waiver clauses. It is more than a little strange that it recognizes implied integration. Call an integration rule that requires parties to expressly state their intent to integrate a "strict express integration rule." A strict express integration rule does not include an implied prong. There are two reasons to think firms would do better with such a rule.

First, absent an integration clause, interpretation of the parties' intent to integrate is likely to be more expensive, less accurate, and more difficult to predict. Rather than enforce the writing's express terms, a court must infer what the parties probably intended its legal effect to be - either from the writing alone (a hard implied integration rule) or from the writing plus extrinsic evidence (a soft implied integration rule). In either case, the evidence will be circumstantial at best, which means outcomes that are both less predictable and more prone to error. And the interpretation of implied meanings is always more resource-intensive and less certain than is the interpretation of express ones. One might guess that on this basis alone sophisticated parties, who value cheap, accurate and predictable adjudication, are likely to say when they intend a writing to be integrated.

Second, firms are ex hypothesi highly responsive to legal rules. Just as we can expect a plain meaning rule to cause sophisticated parties to invest more 
to express their agreement clearly, ${ }^{58}$ so a strict express integration rule will make it all the more likely that sophisticated parties will add an integration clause to writings they intend to be final statements of terms, especially since the costs of doing so are so low. If the law were to require firms who wish to integrate a writing to say so, the vast majority would, under the above assumptions, do just that, adding to the rule's advantages.

Of course a strict express integration rule would increase drafting costs. And some parties who intend a writing to be a final statement of terms might forget to say so in it. But those costs should be weighed against the potentially large gains in accuracy and predictability, as well as reduced litigation costs. So long as firms are largely responsive to the integration rule, there seems little to be gained and much to be lost by recognizing implied integration.

To my knowledge, no one who recommends formalist rules of interpretation for agreements between firms has suggested a formalist integration rule of this type. Eric Posner, who advocates a hard parol evidence rule for certain categories of transactions, does not say that those parties should be required to express in words their intent to integrate. ${ }^{59}$ Jody Kraus and Robert Scott argue that courts should respect parties' choice of framework rules, or "contractual means," including their choice of a rule of interpretation. But when Kraus and Scott discuss the parol evidence rule, they simply state that courts "have devised various neutral tests for determining whether parties intended to integrate part or all of their agreement into a final, legally enforceable writing." $" 60$ And though Alan Schwartz and Robert Scott recommend a hard integration rule for agreements between firms, ${ }^{61}$ they also support the "presumption . . . that the contract is fully integrated if it appears final and complete on its

58 See, e.g., Schwartz \& Scott, supra note 46, at 572; Scott, Text versus Context, supra note 55, at 322-23.

59 Posner, supra note 45.

60 Kraus \& Scott, supra note 25, at 1047. See also id. at 1052 n.124 ("Courts have long recognized that a writing can be found to be a total integration even in the absence of a merger clause."). The appellate case Kraus and Scott use to illustrate how the parol evidence rule should work dealt with a writing that seems not to have included an integration clause. Id. at 1053-62 (discussing Hunt Foods and Ind. v. Doliner, 270 N.Y.S.2d 937 (App. Div. 1966)). The lower court in the case had applied a soft implied integration rule, concluding that the writing was integrated based on the circumstances surrounding its execution. Hunt Foods \& Indus., Inc. v. Doliner, 49 Misc. 2d 246, 249 (N.Y. Sup. Ct. 1966), rev'd, 26 A.D.2d 41 (N.Y. App. Div. 1966).

61 Schwartz \& Scott, supra note 46, at 589-90. 
face," and argue that such a rule "maximizes party discretion over the content of the legally enforceable contract." 62

It is a little odd for these formalists to adopt such anti-formalist integration rules. In firm-to-firm transactions, party control over integration is not maximized by a rule that allows courts to make judgment calls absent an express statement of the parties' intent to integrate. Exactly the opposite. Assuming arguendo that the evidence supports formalism writ large in this sphere, it also supports requiring firms that want to integrate a writing to say so. That is, it supports a strict express integration rule.

\section{B. Consumer Contracts}

A consumer contract is a contract between an individual buyer acting primarily in her private capacity - the consumer - and a business that regularly sells goods, services, software or other products to such individuals. In a typical consumer contract, the business drafts a set of standard terms without consumer input. The business then gives those standard terms, which are often lengthy and written in technical language, to consumers on a take-it-or-leave-it basis. The consumer pays attention not to the standard terms, but to a few primary terms, such as the price and the description of the product - how well the product will work, its entertainment value, how long it will last, etc. Whereas the primary terms are put in front of the consumer's eyes, the standard terms are listed separately in an accompanying document or on a linked webpage, or they arrive later with the product. The consumer, who is focused on primary terms, almost never reads or comprehends the standard terms, but indicates her assent to them by signing at the bottom of a long document, by clicking a HTML button labeled "I agree," by completing the transaction to which the terms are appended, or by not cancelling the transaction when the terms arrive.

There are important differences between the mechanics of choice in consumer contracts and those in negotiated contracts between firms. In a consumer contract, the parties arrive at the transaction with different incentives, knowledge and cognitive abilities. Businesses that sell to consumers are repeat players. As such, it makes sense for them to invest significant resources, including attorney time, in drafting the standard terms they give to consumers, so as to ensure that those terms serve the business's interests. Consumers do not hire lawyers to read the standard terms they are given, and typically do not have the legal sophistication necessary to fully understand them. And because most consumer transactions are low-value, the risks of significant harm slight, and the business's terms adhesive, it is not rational for the consumer to invest the

62 Schwartz \& Scott, supra note 57, at 960. 
resources it would take to understand the business's standard terms. It is not rational for consumers to read, and in fact most do not. ${ }^{63}$ Thus on one side of a consumer contract is a business sophisticated enough to draft standard terms that serve its interests, and on the other is a consumer who has not read or understood those terms. As the Reporters for the draft Restatement of the Law of Consumer Contracts state, this "asymmetry in information, sophistication, and stakes between the parties to the contract" presents a fundamental challenge to the law of contracts. ${ }^{64}$

Although the mechanics of choice in consumer contracts differ from those in negotiated contracts between firms, the values at stake are similar. Dagan and Heller observe that consumers do not typically want rich relationships with the businesses that sell to them. For consumers, these transactions "are like errands whose friction needs to be minimized if contract is to be loyal to its ultimate normative commitment to autonomy as self-determination." 65 Moreover, when the business is a firm whose primary goal is to maximize its own returns, it would be a mistake for the consumer to think she was entering into a morally thick relationship. Thus Dagan and Heller suggest that consumer contract law be structured to "prevent[] firms from (ab)using consumers' misconceptions of being morally bound to comply with, rather than challenge, unfavorable conditions." 66 The value of a typical consumer contract is not the relationship it creates between the consumer and a business, but the welfare gains to each party. In this respect, consumer contracts are not so different from negotiated contracts between firms: the law should seek to help both sides maximize the gains of trade. Or so I will assume in the analysis that follows.

The asymmetries between the parties to a consumer transaction, however, suggest that considerations of fairness are more salient in this sphere than they are in firm-to-firm transactions. Whereas a firm has the capacity to secure its share of any surpluses of trade, it is not obvious that consumers are always in a position to do so, at least insofar as unread standard terms affect the division.

63 See, e.g., Florencia Marotta-Wurgler, Does Increased Disclosure Help? Evaluating the Recommendations of the ALI's 'Principles of the Law of Software Contracts', 78 U. CHI. L. REv 165 (2011) (finding that almost no consumers read online contracts); Margaret Jane Radin, Taking Notice Seriously: Information Delivery and Consumer Contract Formation, 17 Theoretical InQuiries L. 515 (2016) (describing reasons to doubt that effective notice to consumers is possible).

64 Draft Consumer Contracts Restatement, supra note 44, Reporters' Introduction, at 1 .

65 Dagan \& Heller, supra note 1 , at 81.

66 Id. (citing Tess Wilkinson-Ryan, Intuitive Formalism in Contract, 163 U. PA. L. REV. 2109 (2015)). 
Hence the commonly felt need for oversight of such terms, whether ex ante by regulating permissible terms or ex post by judicial review for substantive unconscionability.

So what should a parol evidence rule for consumer contracts look like? The mechanics of choice in this sphere, and especially the fact that consumers do not read standard terms, suggest that there is little point to adopting an agreement-based parol evidence rule - a rule that conditions integration on the parties' shared intent that a writing serve as a final statement of terms. Consumers care about price and product features. It is almost impossible to get them to pay attention to standard terms ${ }^{67}$ This general truth almost certainly applies to technical terms like integration clauses. No matter what the mechanisms of choice, the mechanics of consumer choice mean that most consumers will not be aware of or understand a contractual provision stating that the standard terms are integrated. Uncomprehending agreement provides no obvious benefits. ${ }^{68}$

That said, there are good reasons to treat a business's written standard terms as integrated against at least some forms of extrinsic evidence. Those reasons derive from the argument for permitting businesses to set standard terms in the first place. Standardization can, under the right conditions, benefit both businesses and consumers. Standardizing terms allows a business to save resources by spreading the costs of drafting over many transactions and by regularizing its performance obligations. In a competitive market, we can expect the business to pass at least some of those savings on to consumers in the form of a lower price.

Of course there is the worry that permitting businesses to unilaterally set standard terms might harm consumers - the fairness concern noted above. Even if the happy story about lower prices is true, there is no guarantee for any given standard term that the resulting price reduction will exceed its substantive costs to consumers. If, for example, an arbitration clause with a class-arbitration waiver effectively prevents consumers from enforcing their

67 For a vivid illustration, see Omri Ben-Shahar \& Adam S. Chilton, Simplification of Privacy Disclosures: An Experimental Test, 45 Legal Stud. 541 (2016) (finding that warning boxes highlighting terms many consumers might find important had little effect on consumer comprehension, decision making or understanding of their legal rights).

68 In fact, agreement without understanding can have negative consequences. Thus Tess Wilkinson-Ryan has suggested that consumers' agreement to predictably and rationally unread terms can cause them to believe that they are bound by terms to which they might otherwise object and which might be legally unenforceable. Tess Wilkinson-Ryan, The Perverse Consequences of Disclosing Standard Terms, 103 Cornell L. Rev. 117 (2017). 
legal rights, it is not obvious that consumers come out ahead, even if they pay a somewhat lower price as a result. And standard terms might have negative externalities or offend our sense of fairness in other ways.

If we are worried that businesses will use their unilateral power to impose inefficient or unfair terms, the solution is not to insist that consumers make more informed choices. All the evidence suggests that the mechanics of consumer choice are relatively fixed. A mechanism has not yet been invented that will secure consumer comprehension of terms. The solution is, rather, to set substantive limits on the content of the standard terms firms can choose, either through ex ante regulation, e.g., with lists of mandatory or prohibited terms, which one finds in European law, or ex post judicial scrutiny, in the United States most commonly by way of the unconscionability defense.

Assume for the sake of argument that we have or could construct a system of substantive checks that permits businesses to set standard terms in a way that increases welfare on both sides. (This is an admittedly ambitious assumption. But what else could justify the existing practice of enforcing terms set unilaterally by businesses?) Such a system can realize the advantages of standardization only if individual consumers do not have the power to alter a business's standard terms. The general rules of contract construction, however, can permit just that. Under Article Two of the Uniform Commercial Code, for example, if one party makes a counter proposal with different or additional terms, subsequent performance by the other can either operate as an acceptance of those terms or, in some circumstances, extinguish contrary terms in the earlier offer. ${ }^{69}$ Under such a rule, a consumer might alter a business's standard terms by sending the business a pre-purchase message proposing an alternative term, knowing the message will likely be lost in the shuffle of corporate bureaucracy. If the business then fulfills the order, it might unwittingly accept those terms or alter its own. Though the individual consumer might benefit from having her proposed term included in the agreement or having the business's standard term deleted, the result would be a system of contracting that would ultimately cost all consumers. The costs would come from a combination of business-side expenses associated with the nonstandard terms and business-side policies designed to protect against such consumer-side modifications. In a competitive market, both costs would be passed on to consumers in the price. In short, if standard terms can benefit all parties, then a rule that thwarts individual consumer attempts to modify standard terms benefits both consumers and businesses.

69 The above is a much-simplified description of the rule in U.C.C. § 2-207 (Ам. LAW Inst. \& UNIF. LAW COMM'N 2002). 
All this suggests treating standard terms in consumer contracts as completely integrated against consumer-side communications. In other words, a consumer should not be permitted to introduce her own extrinsic communications as evidence of terms that are contrary or additional to the business's standard terms.

What about business-side communications? Such communications might include parol representations to consumers generally, such as in mass advertising, or parol agreements that the business's agents might enter into with a single consumer. A business might have good reasons to want to integrate standard terms against such parol communications. It might, for example, want to protect itself against the risk that one of its employees will misrepresent to a consumer the standard terms, or make promises or assurances that extend beyond those terms. Integration can reduce such agency costs, producing savings that the business can pass on to consumers in the form of lower prices.

These considerations might be compelling if consumers typically read and relied on standard terms or understood that standard terms are integrated, putting them on notice not to take parol statements seriously. But we know that neither is the case. When it comes to rogue agents, businesses are the cheapest cost avoiders. We can expect much better results if businesses undertake the costs of training and monitoring to ensure that employee communications accord with standard terms, rather than relying on consumers to read standard terms and recognize when not to rely on an employee's promises or representations. The example illustrates a broader principle. As the Reporters for the draft Restatement of the Law of Consumer Contracts put the point, "Since the standard contract terms do not represent a joint effort by both parties of drafting and memorializing a negotiated agreement, there is less justification to allow them to override business-side affirmations or promises made to the consumer." ${ }^{\text {70 }}$ In fact, it is difficult to see why a predictably unread standard term in a consumer contract should ever prevent the enforcement of other affirmations or promises that the consumer is likely to see and understand.

The upshot of the above discussion is threefold. First, the mechanics of choice in the sphere of consumer contracts militate against an agreement-based integration rule. Whether standard terms are integrated should not depend on

70 Draft Consumer Contracts Restatement, supra note $44, \S 8 \mathrm{cmt}$. 3 . The draft Restatement's treatment of the parol evidence rule has shifted over time. As of the final substantive edits to this Article, the most recently published version was the April 17, 2017 Discussion Draft. Section 8 in that draft described a multipart parol evidence rule that differs significantly from the rule recommended in this section. A subsequent samizdat and as of yet unpublished draft has a revised section 8 that better accords with the analysis in this section. 
the parties' shared intent to integrate. ${ }^{71}$ Second, there is a plausible welfarist argument for treating all standard terms as completely integrated against consumer-side communications. Third, the mechanics of consumer choice also suggest that standard terms never be integrated against communications by the business. Together these points suggest for consumer contracts a mandatory or default rule that standard terms are completely integrated against consumer-side communications, and a mandatory rule that they are not integrated against business-side communications. If the consumer-side component of the rule is a default, a business could opt-out of it by including something like an anti-integration clause in its standard terms - though it is not obvious why any business would want to do so. Under no circumstances, however, should a business be able to integrate its standard terms against its own communications. That is, the limited effect of any integration should be mandatory.

The above analysis suggests that the generic parol evidence rules on the books are ill-suited both to negotiated contracts between firms and to consumer contracts. With respect to the former, we would do better with a hard strict express integration rule, one that requires firms to express their agreement to integrate a writing in words and that treats such words as dispositive. With respect to the latter, we would do better by rejecting an agreementbased integration rule and treating standard terms as automatically integrated against extrinsic consumer-side communications and never integrated against extrinsic business-side communications. The reasons for these different rules do not turn on differences between the values at stake in these spheres of contracting. Those values largely overlap. They turn instead on the mechanics of choice in each sphere, which recommend different mechanisms of choice and sometimes restricting parties' ability to choose.

71 Wigmore, who was influential in establishing the modern agreement-based parol evidence rule, also recognized that some types of legal documents are subject to "compulsory integration," in which case the parties' agreement to integrate is unnecessary. See Wigmore, supra note 19, at $\S \S 2450-53,3455-64$ (discussing "Integration required by Law"). 


\section{Conclusion: Implications for a Choice Theory OF Contract}

The above analysis illustrates the value of attending both to the mechanics of choice and to the legal mechanisms of choice when thinking about how one might tailor legal rules to the different spheres of contracting. Dagan and Heller argue that "application of familiar contract concepts .... should vary depending on the normative concerns driving different contract types." 72 But even if we hold normative concerns constant — as the above analyses of negotiated contracts between firms and of consumer contracts largely do - the mechanics of choice can recommend varying the rules of contracting. These variations can include both differences in the mechanisms of choice that the law provides parties and differences in the choices parties are empowered to make, including sometimes limiting those choices. More generally, the quality of choice matters. Party choice adds value when, given the local mechanics of choice, there exist legal mechanisms of choice that in practice enhance party autonomy.

The above discussion only begins to address these issues. For one thing, parol evidence rules govern, in Dagan and Heller's vocabulary, parties' ability to choose contract terms, as distinguished from their choice among pre-established contract types. The mechanics of choice are also relevant to thinking about whether and how the law should provide choice among contract types. It is not enough, for example, to simply say that workers should be given a choice between being employees and being independent contractors. ${ }^{73}$ We need to know more about whether, given the mechanics of choice in this sphere, there exist mechanisms that in practice will give workers the ability to make valuable choices between those forms. ${ }^{74}$ The same holds true for giving consumers a choice between contract types, as illustrated by Part I's discussion of the consumer opt-out provisions in Texas's Deceptive Trade Practices and Consumer Protection Act.

In addition, the above analysis considers two spheres in which similar values are at stake. Maximizing the welfare gains for each party is paramount in each. It might be that mechanisms of choice should also vary depending on the normative concerns of one or another sphere of contracting. In contexts in which we want contract law to support thicker moral relationships or forms of community, for example, yet other variations on the parol evidence

72 Dagan \& Heller, supra note 1 , at 7.

73 Id. at 112 .

74 Dagan and Heller recognize something like this concern when they discuss possible reasons for limiting freedom of contract. $I d$. at 130 . 
rule might be appropriate. If, for example, society's reasons for enforcement involve the parties' actual moral obligations to one another, we might want to make it more difficult for parties to prevent courts from examining extrinsic evidence of their actual agreement. ${ }^{75}$ A complete choice theory of contract would address not only what parties in various contracting spheres should be able to choose, but also the mechanisms of choice that best serve the normative concerns within each sphere.

Although there remains more to say, the above discussion is enough to demonstrate that contract theorists should pay more attention both to the mechanics of choice and to the available mechanisms of choice. Dagan and Heller say a lot about giving parties the power to choose and the choices that should be available to them. They say much less about the mechanics and available mechanisms of choice - how parties make legally efficacious choices. But it is not enough to argue in the abstract that a commitment to party autonomy allows us to resolve conflicts between and disagreements about the values within any given sphere of contracts. The availability of that solution depends on the actual mechanics and available mechanisms of choice within each sphere. Party choice can operate to enhance autonomy and resolve competing values only when parties are willing and able to choose. Whether and where this is the case is relevant to any theory of contract law, including the choice theory.

75 I have elsewhere made a related argument for adopting different legal rules for determining parties' intent to contract in four contexts: gratuitous promises, preliminary agreements between firms, agreements between spouses, and reporters' promises of confidentiality. Gregory Klass, Intent to Contract, 95 VA. L. REV. 1437, 1469-99 (2009). The law does and should adopt rules for interpreting parties' intent to contract depending on the "different balances between the sometimes conflicting reasons the law has for holding promisors liable for their breaches." Id. at 1442 . 